\title{
Proof of Concept of a Novel PEM Fuel Cell Stack Design with Hydraulic Compression
}

\author{
Ulrich Rost ${ }^{1,2}$, Cristian Mutascu ${ }^{1}$, Jeffrey Roth ${ }^{1}$, Christoph Sagewka ${ }^{1}$ and Michael Brodmann ${ }^{1}$ \\ 1. Westphalian Energy Institute, Westphalian University of Applied Sciences, Gelsenkirchen D-45145, Germany \\ 2. Faculty of Industrial Chemistry and Environmental Engineering, Politehnica University Timisoara, Timisoara 300222, Romania
}

Received: July 03, 2015 / Accepted: August 03, 2015 / Published: September 30, 2015.

\begin{abstract}
In this study, a novel design concept for PEMFC (polymer electrolyte membrane fuel cell) stacks is presented with single cells inserted in pockets surrounded by a hydraulic medium. The hydraulic pressure introduces necessary compression forces to the membrane electrode assembly of each cell within a stack. Moreover, homogeneous cell cooling is achieved by this medium. First, prototypes presented in this work indicate that, upscaling of cells for the novel stack design is possible without significant performance losses. Due to its modularity and scalability, this stack design meets the requirements for large PEMFC units.
\end{abstract}

Key words: PEMFC, modular stack design, hydraulic compression, homogeneous cooling.

\section{Introduction}

In the year 2050, Germany intends to generate over $80 \%$ of its electrical energy by renewable sources [1]. To succeed in transforming, the German energy sector towards this high share of renewable energy sources huge effort has to be made in improving the electrical grid infrastructure as well as in extending energy storage. To fulfil carbon dioxide emission targets, it is common sense to result in carbon free strategies.

Producing hydrogen $\left(\mathrm{H}_{2}\right)$ and oxygen $\left(\mathrm{O}_{2}\right)$ in water electrolyzers is a potential solution for using excess energy in periods of low demand [2]. Storing large amounts of $\mathrm{H}_{2}$ in caverns under ground and transportation of it in pipelines is shown at few locations worldwide [3]. In order to generate electrical energy in times of high demand, fuel cell systems can be powered by $\mathrm{H}_{2}$ and $\mathrm{O}_{2}$ or air. Due to high power density and dynamic part load operation, PEM (polymer electrolyte membrane) based fuel cell or electrolyzer systems are appropriate for this purpose $[4,5]$.

Corresponding author: Ulrich Rost, M.Eng. (Ph.D. candidate), research fields: hydrogen energy systems and energy storage. E-mail: ulrich.rost@w-hs.de.
The NOW (national organization for hydrogen in Germany) calculated the demand for hydrogen energy systems as positive and negative supply for varying power demand for the German energy economy in 2025 to be in the range of a up to $5 \mathrm{GW}$ [6]. German demonstration projects combining renewable energy sources with hydrogen systems, like " $\mathrm{H}_{2}$ Herten" or "Falkenhagen", started operation within the year 2014 $[7,8]$.

The main component in PEMFCs (polymer electrolyte membrane fuel cells) is the MEA (membrane electrode assembly). MEAs for PEMFCs consist of an ions conducting but electrical insulating membrane, which is coated from both sides with catalytic material (CCM (catalyst coated membrane)) and, furthermore, an electrical conducting GDL (gas diffusion layer) on the anode as well as on the cathode side. Such a MEA is placed between two pole plates with gas channels (flow field). Together these components form a single fuel cell (Fig. 1). $\mathrm{H}_{2}$ and $\mathrm{O}_{2}$ or air (about $21 \% \mathrm{O}_{2}$ ) are supplied over the flow field and finely distributed to the catalyst due to the high porosity of a GDL. $\mathrm{H}_{2}$ is delivered to the anode and $\mathrm{O}_{2}$ is delivered to the cathode, where product water evolves $\left(\mathrm{H}_{2}+1 / 2 \mathrm{O}_{2}\right.$ 


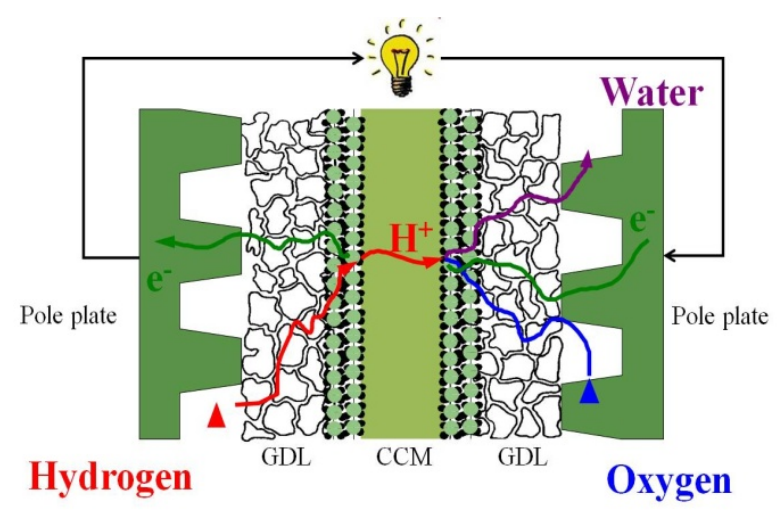

Fig. 1 Schematic drawing of a PEMFC in cross section.

$\rightarrow \mathrm{H}_{2} \mathrm{O}+\Delta \mathrm{H}_{\mathrm{L}}$ with $\Delta \mathrm{H}_{\mathrm{L}}$ equals $3 \mathrm{kWh} \cdot \mathrm{m}^{-3}$ according to the LHV (lower heating value) of $\mathrm{H}_{2}$ ) [9-12].

Typical fuel cell stacks consist of several single fuel cells connected electrically in series which increases stack voltage at constant current. To reduce electrical resistance, pole plates are constructed in bipolar design, so that a flow field is arranged on each side of the plates. Mono-polar plates are placed on the stacks extremities with a flow field only on one side. Furthermore, special pole plates which have channels for cooling water can be placed within the stack to protect it from overheating. Over two strong endplates which are pulled together by tie bolts, necessary compression forces are induced to improve contact resistance between the electrode components as well as catalyst contact to the membrane [12].

To reduce reactance within PEMFC stacks without setting down porosity of the electrode's layers, an optimal compression over the whole cell surface is needed. Moreover, well distributed current density is a central requirement for PEMFC systems to avoid hot spots which may accelerate fuel cell degradation and malfunction [13-21].

In this work, a novel PEMFC stack design is presented which offers homogeneous operation condition for each cell of a stack by hydraulic compression. Inherent stack cooling by a hydraulic medium is a further advantage of the described stack design. Two laboratory scale prototypes indicate modularity and scalability which are required in order to develop large scale PEMFC systems.

\section{A Modular PEMFC Stack Design with Hydraulic Compression}

A new stack design for electrochemical cells based on hydraulic compression of single cells has been suggested [22-24]. With this stack design, PEMFC systems can be constructed which contain a variable defined number of single cells electrically connected in series over flexible copper ribbon cables. These cells are arranged in flexible pockets within a pressure tank filled up with fluid. At operation cells are fixed within the tank by pressurizing this fluid. However, e.g., for maintenance reasons, pressure can be released so that changing cells is possible.

During operation a hydraulic medium surrounds, each cell of the presented stack design in a way that surface pressure on each cell is identical. The hydraulic pressure within the stack is controlled by a pneumatic actuator. The system's pressure control keeps a constant pressure level. This is necessary at e.g., start-up procedure, when stack temperature rises to about $70{ }^{\circ} \mathrm{C}$ to $80{ }^{\circ} \mathrm{C}$ (operating temperature). Furthermore, temperature of the whole stack can be controlled by cooling the hydraulic medium. This guaranties homogeneous temperature distribution for each cell as well as protection against overheating. Waste heat recuperation for a CHP (combined heat and power) system can easily be realized. Hence, operation conditions with this type of stack are nearly ideal, if the parameters of the delivered process gases are constant. In order to deliver gases with identical physical characteristics to each fuel cell, these are connected in parallel to temperature controlled manifolds (for $\mathrm{O}_{2} /$ air as well as for $\mathrm{H}_{2}$ ). Cells have clips which connect them to the gas manifolds (Fig. 2).

However, distribution of necessary gases in series is also possible with another kind of manifold which joins a cell's outlet with the next cell's intake. Due to unfavorable pressure drop after each cell, delivering the gases in series is limited to only few cells.

Two fuel cell stack prototypes with hydraulic compression have been realized so far. Water is used 


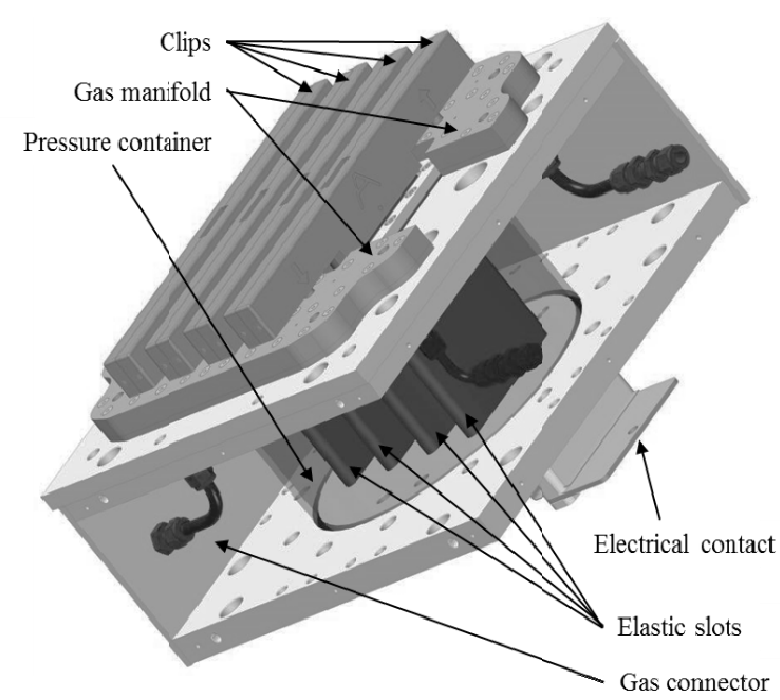

Fig. 2 Schematic drawing of a modular PEMFC stack with four cells.

for cell compression as temperature limit for PEMFCs is about $80^{\circ} \mathrm{C}$. However, high temperature PEMFC systems (up to $200^{\circ} \mathrm{C}$ ) can be realized by using thermal stable oils instead. The first prototype $\mathrm{A}$ is constructed with three single fuel cells with an active cell area of $20.25 \mathrm{~cm}^{2}(45 \mathrm{~mm} \times 45 \mathrm{~mm})$ and a four channels flow field. Photograph of this small scale module is shown in Fig. 3.

The second prototype B is a stack with four cells. Each cell has an active cell area of $182.35 \mathrm{~cm}^{2}(93 \mathrm{~mm}$ $\times 197 \mathrm{~mm}$ ). Flow field is different due to rectangle pole plate design. Furthermore, flow field is designed by 13 parallel channels. Electrical contacts are realized at back side of the stack.

\section{Experiments}

One main advantage of the presented novel stack design is homogeneous cell compression due to hydraulic stack pressure. In order to determine pressure distribution over the active cell area, investigation is carried out with pressure sensitive film from FUJIFILM $^{\circledR}$. For qualitative determination a film type Prescale Super Low Pressure LLW (6-25 bar) is used. Pressure distribution is compared to a typically compressed PEMFC stack (four tie bolts, $20 \mathrm{~mm}$ pressure plate) with identical flow field geometry as for

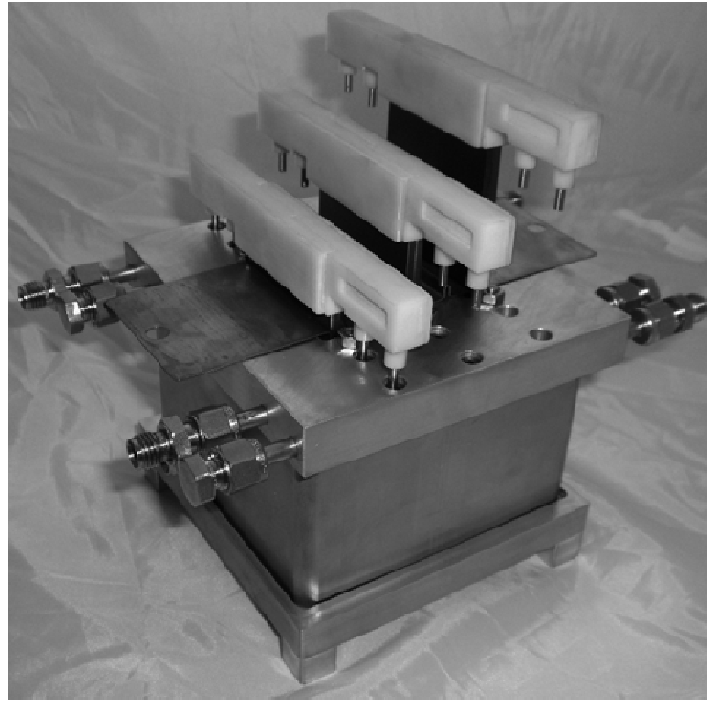

Fig. 3 Photograph of a PEMFC stack with hydraulic compression.

the small prototype (four channels flow field, GDL pocket geometry, sealing).

Uniform current distribution is expected due to homogeneous compression and heat transfer to the hydraulic medium. Regarding the investigation of investigation on current density distribution, a special pole plate has been developed for the small scale PEMFC prototype which offers eight active segments. Flow field design (four channels flow field, GDL pocket geometry, sealing) is identical to standard pole plates for prototype A. Insulation between the segments is achieved by epoxy resin. The active geometrical cell area is decreased due to epoxy frames around each segment. One segment has a geometrical area of $2 \mathrm{~cm}^{2}$ resulting in an active cell area of $16 \mathrm{~cm}^{2}$ (Fig. 4). Each segment is connected to a shunt resistance with $0.1 \mathrm{ohm}$. Voltage drop at operation is measured. A type $\mathrm{K}$ thermocouple is integrated into each segment. Temperature is monitored simultaneously.

In order to proof the novel modular design concept for PEMFC stacks based on hydraulic compression, operation characteristics have been determined at laboratory conditions. Stack housing, cell slots and pole plates for the presented prototypes with hydraulic compression are manufactured at the laboratory's workshop. For both stacks pole plates are milled from 


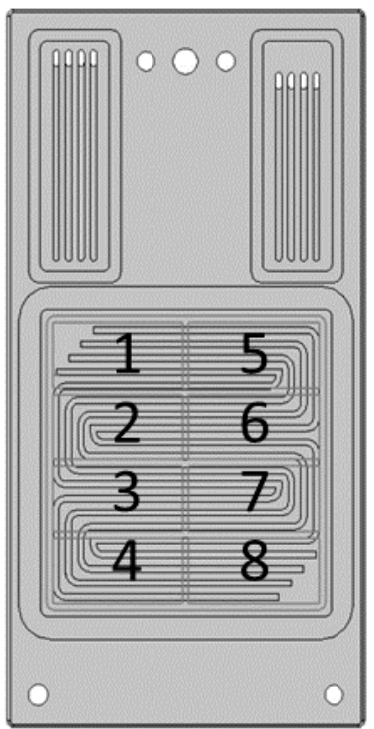

Fig. 4 Schematic drawing of a segmented pole plate (eight segments).

graphite (Schunk Kohlenstofftechnik type FU4413/7) due to its high electrical and thermal conductivity.

MEAs for the fuel cell prototypes have been prepared by commercially available components from Gore ${ }^{\circledR}$. CCM type Primea ${ }^{\circledR}$ FCM and GDL type Carbel ${ }^{\circledR}$ GDM CNW20B have been used. Cell assembly is handmade.

Both stacks are characterized according to their polarization behavior in a full automated test bench with process media treatment and monitoring. Polarization curves for the presented fuel cell stacks are determined by an electronically controlled load type Höcherl \& Hack1 ZS1806NV at constant current mode. Load current is increased step wise (1 A for $2 \mathrm{~s}$ per step). Current and corresponding voltage are measured simultaneously.

Stacks are investigated in $\mathrm{H}_{2}$ /air operation at room temperature. Stacks have start-up condition. MEAs are conditioned by fast cycling procedure according to the Gore ${ }^{\circledR}$ data sheet. $\mathrm{H}_{2}$ with high purity 6.0 is delivered with slightly overpressure of 0.2 bar. Hydrogen is circulated by a diaphragm pump from the anodic outlet to the anodic intake in order to save fuel. Only the amount of consumed $\mathrm{H}_{2}$, is fed to the anodic gas path. Ambient air is delivered to the cathode by a diaphragm pump. Mass flow, temperature and pressure of the feed gases are detected. All measures are logged into a central data base. Air and hydrogen are delivered without additional humidification. Air stoichiometry is set to $\lambda=4$ which means four times more oxygen is delivered to the fuel cell as would be needed for an entire reaction. The $\lambda$-control is implemented in the test bench's PLC (programmable logic controller).

\section{Results and Discussion}

\subsection{Pressure Distribution}

In order to visualize cell compression due to hydraulic medium, pressure distribution has been analyzed by the aid of pressure sensitive film. Pressure distribution for each fuel cell within prototype $\mathrm{A}$ is compared with a mechanically compressed fuel cell stack (Fig. 5 [25]).

It becomes obvious that, the mechanically compressed cells (Figs. 5a-5c) show a typical inhomogeneous pressure distribution according to the four tie bolts of the investigated stack, via which compression forces are induced. This result underlines that, homogeneous compression is a serious issue even for small PEMFC stacks with only few cells. In contrast to the mechanically compression, the pressure distribution within the hydraulically compressed test cells is homogeneous (Figs. 5d-5f). This nearly ideal compression can be explained by the pressure medium which surrounds each cell of the novel test stack completely. Therefore, at any point within the pressurized stack, the same pressure forces affect the single fuel cells.

\subsection{Determination of Current Density and Temperature Distribution}

Current density distribution and temperature distribution measurements are carried out for $15 \mathrm{~min}$ at constant current (4, 8 and $16 \mathrm{~A})$. Every second, voltage drop over the shunt is measured automatically by the aid of an analog input module type Beckhoff EL3068 (0-10 V, 12 bit resolution). Current density for each segment is determined from Ohm's law. Temperature 


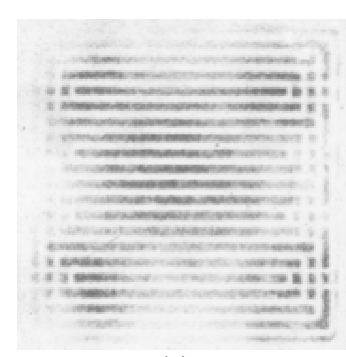

(a)

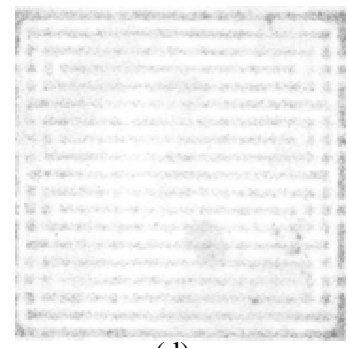

(d)

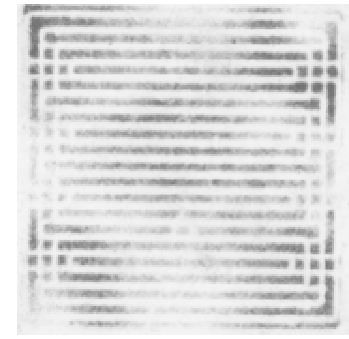

(b)

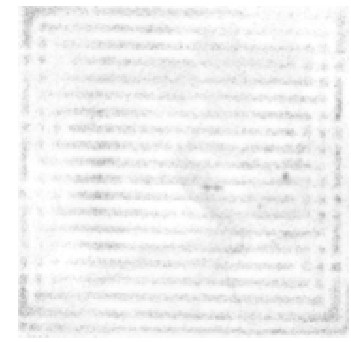

(e)

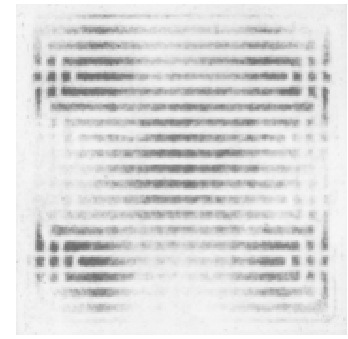

(c)

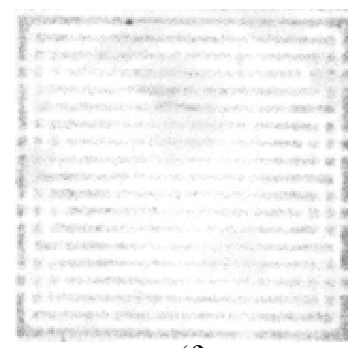

(f)

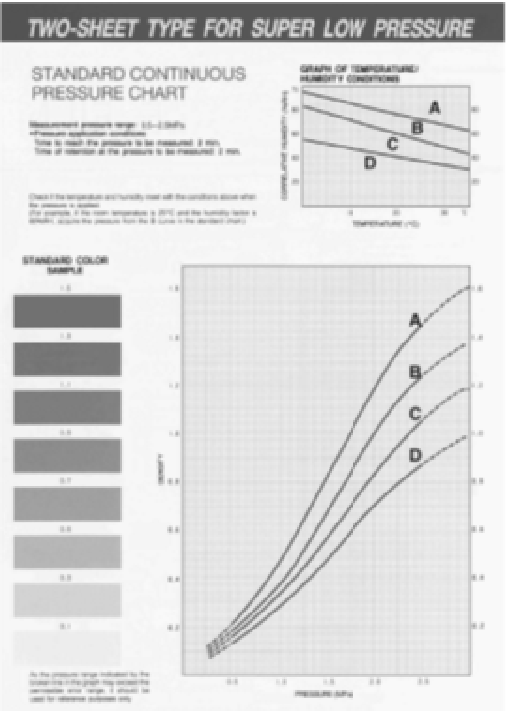

(g)

Fig. 5 Analysis of pressure distribution over the active cell area by pressure sensitive film ((a)-(c): mechanical compression; (d)-(f): hydraulic compression; (g): measuring scale).

is measured by a type $\mathrm{K}$ thermocouple module Beckhoff EL3318 (eight channels, $0.1{ }^{\circ} \mathrm{C}$ resolution). Results of current density and temperature distribution measurements are presented in Figs. 6 and 7. Relative deviation from arithmetic average current density is given in per cent.

Segments No. 4 and No. 8, which are situated near to the gas outlet, show negative deviation from average current density for all three measurements. Especially, current density of segment No. 4 is lowest for all measurements carried out. This may be an evidence for gas flow differences within the flow field at this specific segment, as partial pressure is decreased with the length of the flow field (due to gas consumption).

However, it becomes obvious that, current density over the flow field is homogeneously distributed as a result of homogeneous operation conditions. For constant current operation at $4 \mathrm{~A}$, current density determined for each segment differs from $-4.8 \%$ to $+2 \%$ from the average value of $0.25 \mathrm{~A} \cdot \mathrm{cm}^{-2}$. For operation at $8 \mathrm{~A}$ (average of $0.5 \mathrm{~A} \cdot \mathrm{cm}^{-2}$ ) and $16 \mathrm{~A}$ (average of $1 \mathrm{~A} \cdot \mathrm{cm}^{-2}$ ), the measured deviation is $-7.7 \%$ to $+4.3 \%$ and $-7.1 \%$ to $+4.6 \%$, respectively.

As a result of cooling by the hydraulic medium temperature for each segment is nearly identical. Mean temperature of each segment measured simultaneously to current density distribution is in the range of $33.0^{\circ} \mathrm{C}$ $\pm 0.8^{\circ} \mathrm{C}$ at constant current operation with $4 \mathrm{~A}$. For operation at $8 \mathrm{~A}$ as well as $16 \mathrm{~A}$, the mean segment temperature is $33.8^{\circ} \mathrm{C} \pm 0.6{ }^{\circ} \mathrm{C}$ and $40.2^{\circ} \mathrm{C} \pm 1.2^{\circ} \mathrm{C}$, respectively. As a result of increasing, waste heat cell temperature rises with higher load current.

\subsection{Polarization Behavior of Presented PEMFC Prototypes}

Fig. 8 shows polarization curves of prototypes A and B. Current density is presented as a function of stack voltage as well as cell as of voltage of the first cell of each stack (U1). Open circuit voltage of both fuel cell prototypes is in the range of $0.9 \mathrm{~V}$ for each cell. For prototype A $2.7 \mathrm{~V}$ and, respectively, for prototype B, $3.7 \mathrm{~V}$ has been measured in open circuit. At fuel cell operation, voltage drops nearly linearly with the applied load up to the point of maximum power output. This result from the internal resistance as well as from ionic membrane losses.

For nearly ambient conditions (stack temperature at $30^{\circ} \mathrm{C}$, operation with un-humidified ambient air) MPP (maximum power point) of fuel cell prototype $\mathrm{A}$ is found for an output voltage of $1.15 \mathrm{~V}\left(27 \mathrm{~W} / 0.43 \mathrm{~W} \cdot \mathrm{cm}^{-2}\right)$. 


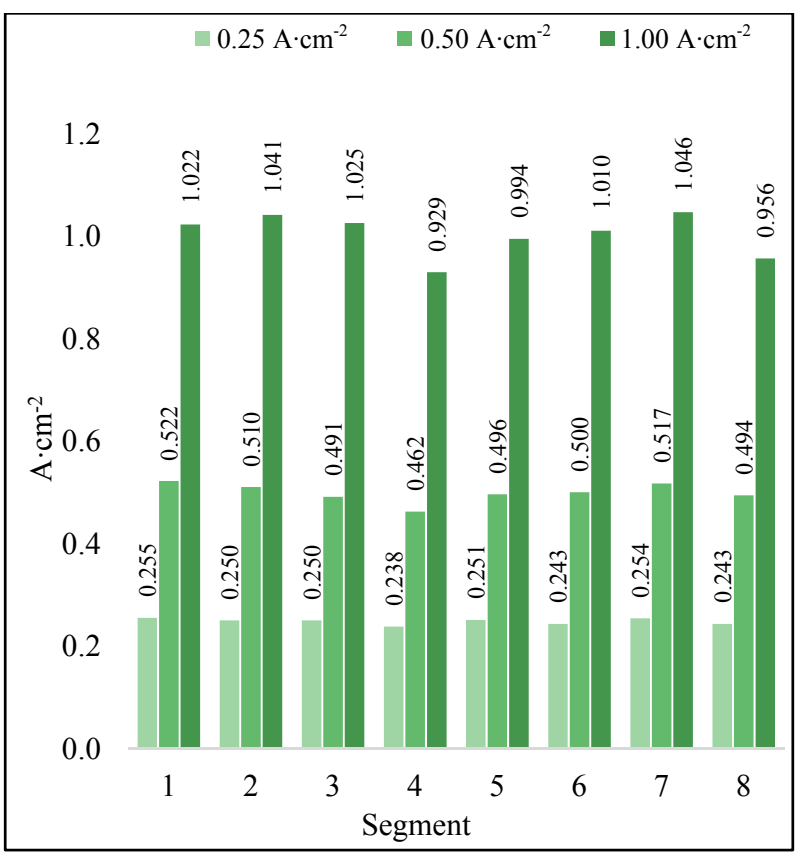

(a)

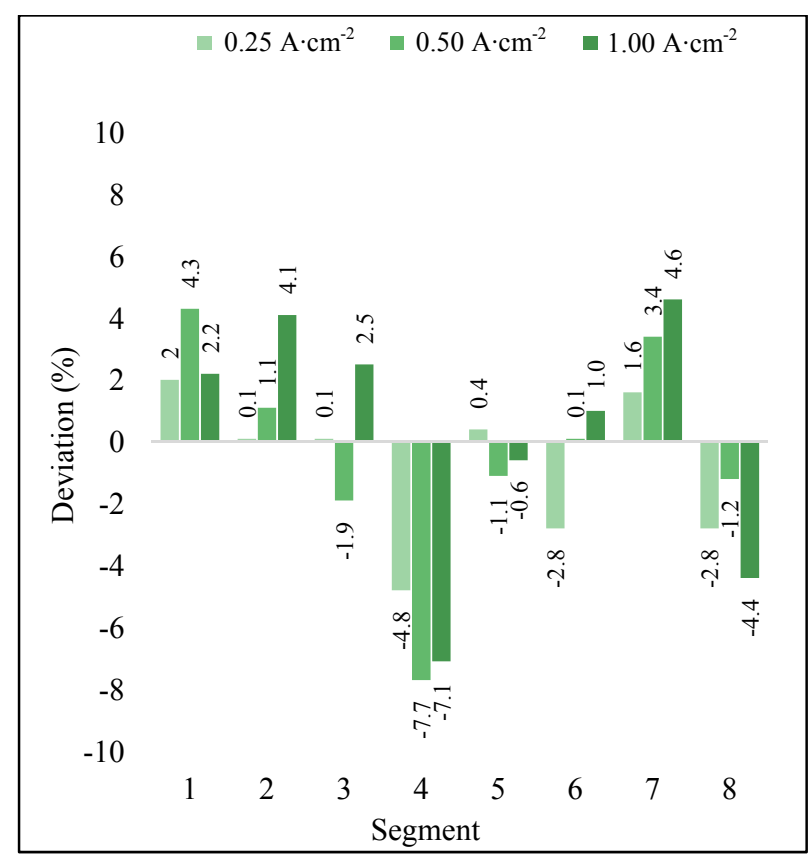

(b)

Fig. 6 (a) current density distribution and (b) deviation from arithmetic average current density for 4, 8 and 16 A load current.

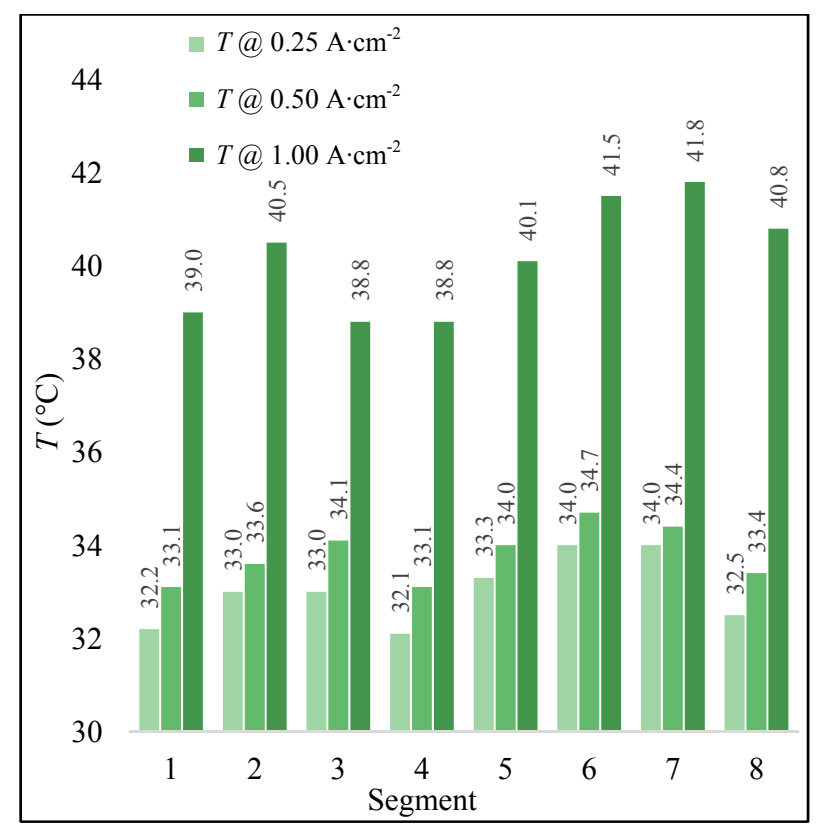

Fig. 7 Temperature distribution for 4, 8 and 16 A load current.

Maximum power output of fuel cell prototype B is $290 \mathrm{~W}$ $\left(0.38 \mathrm{~W} \cdot \mathrm{cm}^{-2}\right)$ at an output voltage of $1.92 \mathrm{~V}$. Although active cell area is different by a factor of nine specific maximum power output is in the same range. As linear upscaling of a pole plate design has not been possible for prototype B, slightly design differences have been necessary (e.g., channel length, channel diameter or channel number). Therefore, differences in power output of prototypes A and B occur mainly due to different flow field designs. Furthermore, increase of resistance losses is likely due to higher current of prototype B (150 A @ MPP). However, increasing diameter of the connecting copper cables can be an appropriate solution.

Obtained power density for the presented prototypes is similar to specific power output reported for commercially available MEA based PEMFC test cells with mechanical cell compression [26-28]. Further improvement for PEMFC stacks with hydraulic compression is expected by the optimization of pole plates, especially, the flow field. However, the novel stack design offers specific advantages. Very large cells with any planar shape can be realized. Waste heat recuperation can easily be maintained (for higher operation temperature). Furthermore, each cell can be exchanged due to the modular stack construction with separate slots. 


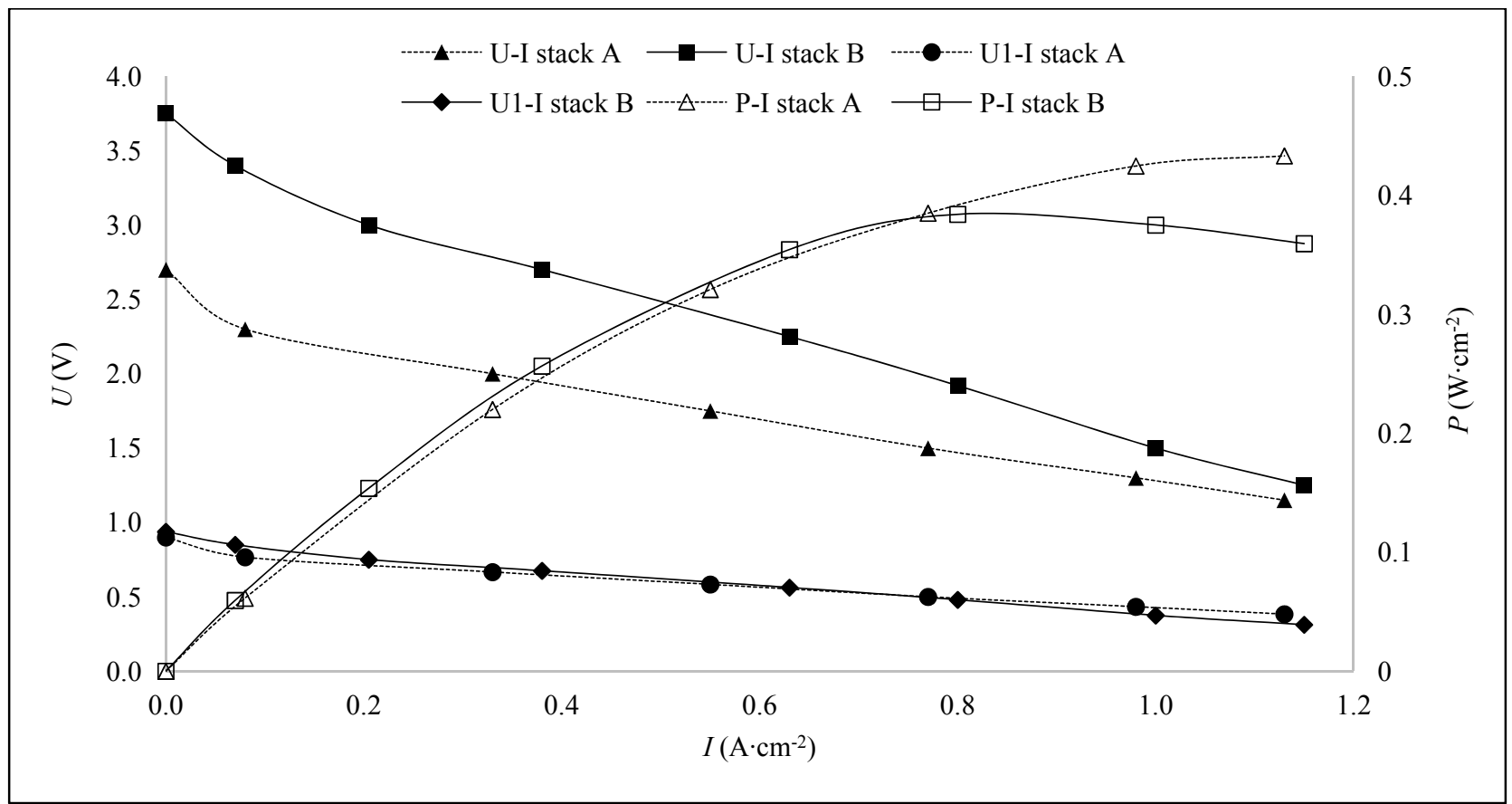

Fig. 8 Polarization curves on cell level (U1) as well as on stack level for PEMFC prototypes A and B.

The influence of hydraulic compression on PEMFC operation characteristic in long term tests is matter of a prospective study.

\section{Conclusions}

Results indicate that, upscaling the presented small cell geometry for PEMFC prototype A to a factor of nine decreases specific power output of just $12 \%$. Furthermore, current density distribution is homogeneous (about $\pm 7 \%$ over the active cell area) due to hydraulic compression. It is expected that, current density for the larger prototype is also well distributed.

It can be concluded that, upscaling effects known for state of the art PEMFC stacks are of minor importance due to even cell compression and cooling by the surrounding hydraulic medium. Very large planar cell geometries can be realized. Special cooling plates which are necessary in large state of the art PEMFC stacks are not needed for the novel stack design.

Increasing number of cells from three to four does not affect specific power output significantly. This effect occurs due to nearly identical operation condition for each cell of a stack. Therefore, it can be concluded that, designing large scale stacks with any number of cells is possible. This may attract PEMFC based stationary applications in the near future.

Few design changes are needed to convert the presented stacks into energy systems with waste heat recuperation, e.g., a CHP system for household heating can operate by heat exchanging a PEMFC stack's inherent cooling water which is also used for cell compression.

The possibility to exchange single cells of the stack may be useful for maintenance. Cells which are degraded after some thousand operating hours can be replaced without affecting the housing. For prospective stationary applications with a lifetime of several years, the possibility to maintain the stack could be an advantage for the presented novel stack design with hydraulic compression.

\section{Acknowledgments}

The presented study has been carried out in the scope of research projects funded by the public, financially supported by the ministry of innovation, science and research of North Rhine Westphalia, Germany, within 
the program "Ziel2.NRW EFRE (Regionale Wettbewerbsfähigkeit und Beschäftigung)" (funding number: 005-1111-0010) as well as by the German Federal Ministry of Economic Affairs and Energy within the program "Zentrale Innovation Mittelstand" (funding number: KF2687002ZG3).

\section{References}

[1] German Federal Ministry of Economic Affairs and Energy, German Federal Ministry for the Environment, Nature Conservation, Building and Nuclear Safety. 2010. "Energiekonzept." German Federal Ministry of Economic Affairs and Energy, German Federal Ministry for the Environment, Nature Conservation, Building and Nuclear Safety. Accessed May 17, 2015. http://www. bundesregierung.de/ContentArchiv/DE/Archiv17/_Anlag en/2012/02/energiekonzept-final.pdf?blob=publicationFil $\mathrm{e} \& \mathrm{v}=5$.

[2] Stolten, D. 2010. Hydrogen and Fuel Cells. Weinheim: Wiley- VCH, 207-26.

[3] Stolten, D. 2010. Hydrogen and Fuel Cells. Weinheim: Wiley-VCH, 121-48.

[4] Ballard. 2010. "Ballard Tests 1 MW PEM Power Plant." Ballard. Accessed May 17, 2015. http://www. h2euro.org/2010/ballard-tests-1-mw-pem-power-plant.

[5] Stolten, D. 2010. Hydrogen and Fuel Cells. Weinheim: Wiley-VCH, 755-86.

[6] Smolinka, T., Günther, M., and Garche, J. 2011. "Stand und Entwicklungspotenzial der Wasserelektrolyse zur Herstellung von Wasserstoff aus Regenerativen Energien.” NOW GmbH. Accessed May 17, 2015. http://www.now-gmbh.de/fileadmin/user_upload/RE_Pub likationen_NEU_2013/Publikationen_NIP/NOW-StudieWasserelektrolyse-2011.pdf.

[7] Klug, K. 2013. "Wasserstoff als Energiespeicher." Presented at the 13th Annual Meeting of the Hydrogen and Fuel Cells Network North Rhine-Westfalia, Düsseldorf, Germany. Accessed May 17, 2015. http://www.brennstoffzelle-nrw.de/fileadmin/daten/jahres treffen/2013/11_Klug_WF-HS-GE_Windstrom-Herten_ NBW20131114.pdf.

[8] E.ON. 2013. "E.ON Inaugurates Power-to-Gas Unit in Falkenhagen in Eastern Germany." E.ON. Accessed May 17 ,

2015. http://www.eon.com/de/presse/pressemitteilungen/presse mitteilungen/2013/8/28/eon-nimmt-power-to-gas-pilotanl age-im-brandenburgischen-falkenhagen-in-betrieb.html.

[9] Zhang, J. 2008. PEM Fuel Cell Electrocatalysts and Catalyst Layers Fundamentals and Applications. London: Springer Verlag, 1-88.
[10] Heinzel, A., Mahlendorf, F., and Roes J. 2006. Brennstoffzellen Entwicklung, Technologie, Anwendung. Heidelberg: C.F. Müller Verlag.

[11] Hamann, C., and Vielstich, W. 1998. Elektrochemie. Weinheim: Wiley-VCH.

[12] Barbir, F. 2013. PEM Fuel Cells Theory and Practice. Waltham: Elsevier.

[13] Zhou, P., Lin, P., Wu, C. W., and Li, Z. 2011. "Effect of Nonuniformity of the Contact Pressure Distribution on the Electrical Contact Resistance in Proton Exchange Membrane Fuel Cells." International Journal of Hydrogen Energy 36 (10) 6039-44.

[14] Asghari, S., Shahsamandi, M. H., and Ashraf Khorasani, M. R. 2010. "Design and Manufacturing of End Plates of a $5 \mathrm{~kW}$ PEM Fuel Cell." International Journal of Hydrogen Energy 35 (17): 9291-7.

[15] Asghari, S., Mokmeli, A., and Samavati, M. 2010. "Study of PEM Fuel Cell Performance by Electrochemical Impedance Spectroscopy." International Journal of Hydrogen Energy 35 (17): 9283-90.

[16] Garcia-Salaberri, P. A., Vera, M., and Zaera, R. 2011. "Nonlinear Orthotropic Model of the Inhomogeneous Assembly Compression of PEM Fuel Cell Gas Diffusion Layers." International Journal of Hydrogen Energy 36 (18): 11856-70.

[17] Park, S. 2013. "Simulation and Experimental Analysis of the Clamping Pressure Distribution in a PEM Fuel Cell Stack." International Journal of Hydrogen Energy 38 (15): 6481-93.

[18] Qiu, D., Yi, P., Peng, L., and Lai, X. 2013. "Study on Shape Error Effect of Metallic Bipolar Plate on the GDL Contact Pressure Distribution in Proton Exchange Membrane Fuel Cell." International Journal of Hydrogen Energy 38 (16): 6762-72.

[19] Wang, X., Song, Y., and Zhang, B. 2008. "Experimental Study on Clamping Pressure Distribution in PEM Fuel Cells." Journal of Power Sources 179 (1): 305-9.

[20] Xing, X. Q., Lum, K. W., Poh, H. J., and Wu, Y. L. 2010. "Optimization of Assembly Clamping Pressure on Performance of Proton-Exchange Membrane Fuel Cells." Journal of Power Sources 195 (1): 62-8.

[21] Pharoah, J. G., and Burheim, O. S. 2010. "On the Temperature Distribution in Polymer Electrolyte Fuel Cells.” Journal of Power Sources 195 (16): 5235-45.

[22] Brodmann, M., Greda, M., Roth, J., and Mutascu, C. 2009. Vorrichtung Zur energieumwandlung, insbesondere brennstoffzellenstack Oder elektrolyseurstack. German Patent DE102,009,057,494 A1, filed December 10, 2009, and issued June 16, 2011.

[23] Brodmann, M., and Greda, M. 2012. "Taschenkonzept Schafft Neue Freiheitsgerade Modulare Stacks Mit Austauschbaren Verschleißteilen." Hzwei 12 (4): 14-5. 
[24] Rost, U., Brodmann, M., Şerban, V. A., Mutascu, C., Roth, J., and Zekorn, B. 2012. "State of the Art PEM Fuel Cells with a Focus on a Modular Fuel Cell Stack with Haydraulic Compression." Scientific Bulletin of the "Politehninica" University of Timisoara Romania Transactions on Mechanics 57 (71): 1-6.

[25] Fujifilm. "Instruction Manual Fuji Prescale Film." Fujifilm Europe GmbH. Accessed September 1, 2015. http://www.fujifilm.eu/fileadmin/products/prescale/media /Two_Sheet_Type_for_Super_Low_Pressure_klein.pdf.

[26] Yan, W. M., Wang, X. D., Lee, D. J., Zhang, X. X., Guo, Y.
F., and Sud, A. 2011. "Experimental Study of Commercial Size Proton Exchange Membrane Fuel Cell Performance." Applied Energy 88 (1): 392-6.

[27] Wang, X. D. 2008. "Effects of Operating Temperatures on Performance and Pressure Drops for a $256 \mathrm{~cm}^{2}$ Proton Exchange Membrane Fuel Cell: An Experimental Study." Journal of Power Sources 185 (2): 1040-8.

[28] Roth, J. 2011. “Optimization of PEMFCs by Applying Hot Pressed MEAs Using Different GDL and Favourable Driving Scenarios for Operation without Humidification." Master thesis, Fachhochschule Gelsenkirchen. 